\title{
Deconstructing Androcentrism in Buddhist Literature Through the Lens of Ethnography: A Case Study of Bhutanese Nuns
}

\author{
*SONAM WANGMO \\ JULI EDO \\ KAMAL SOLHAIMI FADZIL \\ Department of Anthropology and Sociology, Faculty of Arts and Social Sciences, \\ University of Malaya, 50603 Kuala Lumpur, Malaysia \\ *Corresponding author: wangmo.sonam@gmail.com
}

Published online: 20 December 2018

To cite this article: Wangmo, S., Edo, J. and Fadzil, K.S. 2018. Deconstructing androcentrism in Buddhist literature through the lens of ethnography: A case study of Bhutanese nuns. KEMANUSIAAN the Asian Journal of Humanities 25(Supp. 1): 143-165, https://doi.org/10.21315/ kajh2018.25.s1.8

To link to this article: https://doi.org/10.21315/kajh2018.25.s1.8

\begin{abstract}
Traditional androcentric sociology has reinforced biased views of women and portrayed women as silent research objects of minor importance that figure marginally in academic writing, thereby distorting the knowledge base. The same tendencies have been observed in Buddhist religious literature. The bone of contention in the feminist critique of Buddhism is the omission of women from religious literature. Although Buddhist women's spiritual prowess was well documented in early Buddhism in religious literature such as the Therigatha, later Buddhist literature began to demonstrate androcentric tendencies, in most instances completely ignoring the religious lives of women. Since women have been largely sidelined in Buddhist texts, it is important to go beyond textual dimensions to gain deeper insights into women's religious lives. The feminist Buddhist scholar, Rita Gross (2009), in her monumental work, A Garland of Feminist Reflections, emphasised the need to explore various ways other than our own to think, live and practice religion to broaden our horizons to avoid a narrow-minded approach to academic research. Citing two case studies of Buddhist nuns in Bhutan, this paper argues for ethnography as an alternative to traditional text-based scholarship on religious studies whereby women tell their stories and paint their own reality.
\end{abstract}

Keywords and phrases: androcentrism, ethnography, feminist Buddhist methodology, Buddhism, Bhutanese nuns 


\section{Introduction}

The invisibility of women in Buddhist literature is a persistent problem resulting in women's severe lack of opportunities in religious practice as well as their perpetual confinement to minor, often gendered religious roles. The academic study of religion also plays a part in the marginalisation of women. Western scholarship on Buddhism, as this paper argues, adds to the marginalisation of women that is already present in traditional Buddhist scholarship. Nonetheless, emerging trends are beginning to influence the gender imbalance in contemporary religious scholarship, one of which forms the core of this paper - the ethnographic study of the religious lives of women.

In her book, A Garland of Feminist Reflections, Gross (2009) observed that the religious lives of women were fully ignored in the academic study of religion, resulting in the inaccurate portrayal of religion and women's role in religion. She cited the example of scholars who leaned towards understanding Eastern religions such as Hinduism through a Christian lens, thereby excluding women from discussions on Hinduism because they were not part of the text-based Hinduism that includes the Vedas, Upanishads and Shastras. Gross (2009) contended that women were erroneously disregarded in the academic study of Hinduism, which resulted in a lop-sided portrayal of Hinduism as a centrally text-based religion. Nonetheless, contemporary scholars of religious studies are beginning to realise that Hindu women's role in religion has been grossly underestimated as women are the fulcrum of living Hinduism today due to their central role in preserving Hindu religious ceremonies. Gross (2009) further argued that admitting the validity of diverse methods and encouraging them all has dramatically improved the study of religion. For example, Hinduism is now discussed in major academic treatises more holistically, including both its textual and ceremonial aspects. She maintained that such viewpoints and perspectives offer a broader and richer picture than studies focusing on a single angle.

With regard to Buddhist religious literature, Simmer-Brown $(2002,137)$ asserts that Western Tibetology focuses on the institutional aspects of Vajrayāna Buddhism, "almost completely neglecting the contributions, insights, and transmissions of women, which have often been seen as superstitious or merely folk traditions". Gross (1993) and Aziz (1987) attributed this to the essentially patriarchal nature of Western scholarship, which elevates monastic traditions and classical texts, thereby reinforcing the "patriarchal habits of Buddhist institutions in Tibet" (Simmer-Brown 2002, 137). Nonetheless, Western scholarship is beginning to reveal the lives of past female Buddhist practitioners. Examples include Women of 
Wisdom, a collection of biographies of enlightened Buddhist women in Tibet by Tsultrim Allione (2000), Schaeffer's Himalayan Hermitess: The Life of a Tibetan Buddhist Nun (2004) and Sarah Jacoby's (2014) book about the autobiography of Sera Khandro, entitled Love and Liberation. These works represent a trend of uncovering the religious lives of past female masters, although they fall short of representing the lives of contemporary female Buddhist practitioners.

From the perspective of Bhutanese Buddhist literature, which is the focus of this paper, Bhutanese nuns have been mostly invisible. They are hardly ever mentioned in religious biographies or oral stories, and when they are mentioned, they are portrayed as killers (Penjore 2005) or beings of lesser intellectual capacity who require male figures to liberate them from the cycle of samsāra. ${ }^{1}$ Furthermore, nuns remain invisible in contemporary Bhutanese religious literature and modern academic writing (Mittra \& Kumar 2004).

As a corrective measure, cultural feminists emphasise the need to analyse women's everyday reality and provide an accurate picture of a society that is formed by both male and female members. As such, increasing ethnographic research on Buddhist women has emerged in the last two decades, such as Gutschow's (2004) Being a Buddhist Nun: The Struggle for Enlightenment in the Himalayas, which is a study of Buddhist nuns in Zangskar, India; or Falk's (2007) work on Thai maechees, ${ }^{2}$ entitled Making Fields of Merit: Buddhist Female Ascetics and Gendered Orders in Thailand.

This study reveals the androcentric tendencies in Buddhist literature from early Buddhism through present-day Bhutan, demonstrating the various ways in which women have been omitted from history. It exposes factors that contribute to the inaccurate portrayal of women as insignificant actors in a male-dominated Buddhist world. We focus specifically on Vajrayāna Buddhist literature from the Tibetan cultural region, of which Bhutan is very much a part. This research is also an attempt to correct the gender imbalance in Bhutanese religious literature and to move beyond traditional scholarship on women in Buddhism, which is largely text-based. In our inquiry, we undertook ethnographic research on Buddhist nuns in Bhutan, the first study of its kind in this country. The aforementioned omission of women from literature in Bhutan has produced a gap in the literature that must be filled by analysing gendered roles in religious practice amongst ordained Buddhist women. We do so here by focusing on two selected nunneries in Bhutan. This ethnographic research uncovered many fresh and interesting aspects of being Buddhist female mendicants that have not previously been discussed in any religiopolitical ${ }^{3}$ literature about Bhutan. 


\section{Druk Yul: A Religious History of the Land of the Thunder Dragon}

To understand the androcentric tendencies in Buddhist literature on Bhutan, it is essential to begin with a brief overview of the religious and political history of the country. This section explains the deeply entrenched masculine tendencies of Bhutanese literature that have created a distorted perception of women as insignificant bystanders in Bhutan's glorious religio-political history.

Bhutan, or Druk Yul (Land of the Thunder Dragon), is a small country located in the Eastern Himalayas and the only country in the world that recognises Vajrayāna Buddhism as its official religion (Crossette 1995; Wangchuck 2006). The Bhutanese are predominantly Buddhists, and the only other religion accepted in Bhutan is Hinduism, a religion associated with people of Nepali origin (Wangchuck 2006). Vajrayāna Buddhism became Bhutan's state religion in the 17th century, and its fundamental principles are derived from the Drukpa Kagyu school of Vajrayāna (Tibetan) Buddhism (Crossette 1995; Wangchuck 2006).

Bhutanese religious history is very much intertwined with the histories of neighbouring countries. Thus, to discuss Bhutanese Buddhism in isolation from Tibet and India would be inaccurate and would provide a skewed and narrow understanding of the topic. In addition, the Bhutanese inherited much of the androcentric and misogynistic religious literature from their spiritual ancestors.

The religious history of Bhutan can be traced back to India and Tibet, two countries that have an overwhelming influence on the "Land of the Thunder Dragon". Although India (located to the south, west and east) is geographically far more accessible than Tibet (located to the north), Buddhism generally did not enter Bhutan this way, with the exception of the first visit by Guru Padmasambhava, the patron saint of Bhutan. Instead, Buddhism spread to Tibet in the 7th century CE and then to Bhutan within the same century (Wangchuck 2006). It is also assumed that the religious masters of India and Tibet greatly influenced the religious landscape of Bhutan.

The religious history of Bhutan is intertwined with its political history as several key historical figures were both monks and secular rulers. In terms of its religious history, the primordial shamanistic religion, i.e., Bon and Tibetan Vajrayāna Buddhism, shaped the religious realm of Druk Yul to form the blend of Vajrayāna Buddhism seen in Bhutan today.

Bhutan's religious history largely revolves around two prominent male figures, namely, Guru Padmasambhava, who is credited with introducing Buddhism to 
the country and establishing the Nyingma school of Tibetan Buddhism in the 7th century CE, and Shabdrung Ngawang Namgyal, who was instrumental in shaping the religio-political landscape of Bhutan as we know it today. Interestingly, neither Guru Padmasambhava ${ }^{4}$ nor Shabdrung Ngawang came from Bhutan. Guru Padmasambhava was an Indian prince from the Swat Valley in northwestern India (now Pakistan), whereas Shabdrung Ngawang was Tibetan.

Whatever the origins of these historical figures, the religio-political history of Bhutan was almost entirely shaped by men, with the occasional mention of a few queens and wives of famous religious leaders, such as Phajo Drukgom Zhigpo (Phuntsho 2013). These women are merely mentioned in passing. Moreover, women in the religious and political history of Tibet and Bhutan are described as consorts, either for the purposes of tantric practice (Dowman 2000) to elevate a male's spiritual status or to produce male heirs for secular or religious dynasties. The male religious figures who helped spread religion in Tibet and Bhutan were mostly monks, and due to some prophecy or vested interests, they took consorts and produced heirs to maintain their lineage and advance their religio-political dynasties. Throughout this illustrious conquering and spreading of lineages, women, due to androcentric historical reporting, remained invisible and insignificant. Little credit was given to women for their religious practice, spiritual realisations or other contributions. Hence, we know very little about the religious lives of Bhutanese women throughout the history of Buddhism in the country.

\section{Correcting Gender Imbalance in Buddhist Scholarship through the Lens of Ethnography}

Scholarship on gender roles in Bhutan is scarce. Since its inception in 2000, the Journal of Bhutan Studies has not published a single article related to gender roles and discrimination against women. The only work by Bhutanese writers to date that sheds light on gender roles is that of Choden (2005) in her novel, The Circle of Karma. A scholarly article by Mittra and Kumar (2004) published in India provides a broad description of women in Bhutan, although it does not say much about nuns and their socio-religious roles, issues and interactions with larger Bhutanese society. Although isolated studies exist on gendered roles in religious practice in Bhutan that focus specifically on Bhutanese nuns and gender discrimination, all of these studies (Wikan 1996; Crins 2008; Zangmo 2009) are cross-sectional and were conducted during rapid field visits rather than over a prolonged period.

Nuns are mentioned in passing in religious biographies and hagiographies (Tib ${ }^{5}$ : rnam-thar), histories (Tib: chojung) and oral stories (Tib: drung), but 
no analyses exist on the role of nuns in religious practice in Bhutan. There are published works regarding the sexual abuse of nuns in Bhutan and the postmodern dilemma of an old Bhutanese nun (Wikan 1996), but no articles have analysed the roles of younger nuns in the county and culture. Most scholarship on Buddhist women in Bhutan is based on either textual analysis (Aris 1986) or cross-sectional studies of women (Wikan 1996; Crins 2008; Zangmo 2009). Although in-depth studies have been conducted on the role of nuns in religious practice elsewhere in the Himalayas, such as an ethnographic analysis of the lives of Buddhist nuns in Zangskar (Gutschow 2004), similar scholarship is lacking in Bhutan, which is generally overshadowed by Tibet. The travel literature of the British East India Company officers omits the topic of nuns in Bhutan entirely, which may explain the exclusion of Bhutanese nuns from modern Buddhist scholarship due to oversight and obliviousness. The two case studies cited in this paper are significant as they attempt to correct the imbalance in narratives on male and female religious personalities in Bhutan and shed light on the lives and contributions of Bhutanese nuns. This research seeks to fill the gaps by analysing social differentiation in terms of religious practice with a particular emphasis on Bhutanese nuns.

Much literature and criticism exists on monastic education in Bhutan, (e.g., Phuntsho 2005; Denman and Namgyel 2008), but only Denman and Namgyel mention nuns' education, with only one paragraph dedicated to nuns regarding insufficient support for private nunneries that provide monastic education to nuns. Other articles focus exclusively on the education of monks. For example, Phuntsho (2005) conducted a comparative study of traditional education [i.e., monastic (religious) education] and secular education (modern education in English) and analysed the history of monastic education in Bhutan, future trends in monastic education and the impact of modern education on traditional education. However, Phuntsho's work did not consider nuns' monastic education at all, which is unsurprising as nuns lack access to monastic education in Bhutan. Only Penjore (2005), in his analysis of Bhutanese folktales and education, describes the lack of access to monastic education among nuns.

Feminism insists that women be given their proper place as equal members of the human race. Feminist methodology entails rejecting pejorative overtones about women in academic writings and insists on the re-evaluation of works that thrust women into insignificance. The objectification of women is a core basis for feminism and feminist methodology, which breaks down the dichotomies between stereotyped gender roles and the notion of male and female or masculine and feminine. In traditional scholarship, including Buddhist studies, men are regarded as "normal" and women as "other". These dichotomies imply that men are inherently powerful, whereas women lack power (Wallston 1985). Feminism serves to empower women through the redistribution of power such that women 
are no longer treated as insignificant objects of research, "needing to be explained and fitted in somewhere having the same epistemological and ontological status as trees, unicorns, deities, and other objects that must be discussed to make experience intelligible" (Gross 1996, 20).

The Nebraska Sociological Feminist Collective ${ }^{6}$ recommends that research incorporate accounts of women's lives in their own words, analysing the full spectrum of women's social conditions, such as politics, education, race and ethnicity, instead of limiting the scope of inquiry to traditional, stereotyped women's roles such as marriage, family or reproduction (Lughod 1990).

\section{Methodology and Research Setting}

This study adopted a Feminist Buddhist approach as the basic framework for understanding issues surrounding Bhutanese nuns' access to monastic education. We utilised ethnography to analyse the dynamics surrounding religious education for nuns in two nunneries: ${ }^{7}$ one in Eastern Bhutan and another in Western Bhutan. Two months were spent studying each nunnery for a total of four months of continuous field research. Fieldwork at Jachung Karmo Nunnery was conducted from mid-August to mid-October 2012, and fieldwork at Jashar Goenpa lasted from late October to late December 2012. Follow-up fieldwork was conducted in December 2013 and December 2015 to provide updates on the nuns' lives.

The government-run nunnery in the west, Jachung Karmo, is situated in Punakha, whereas the private nunnery in the eastern part of the country, Jashar Goenpa, is located in Pema Gatshel. The rationale for selecting the two regions is that they have the largest concentration of monastic institutions, including nunneries. Moreover, the western and eastern parts of Bhutan are distinctly different, with different languages and ethnic groups, and they maintain separate religious affairs. Therefore, a comparison of nunneries in these very different regions is essential to provide a broader picture of the current situation of Bhutanese nuns.

The main methodology employed in this ethnographic research is participant observation. The researcher employed an array of additional data collection methodologies such as interviews, focus group discussions and daily activities surveys of the nuns in the two nunneries to facilitate an understanding of the worldview of the various actors in this study, namely nuns, monks, laymen and laywomen. Secondary data are relevant Buddhist texts/scriptures/biographies/ hagiographies used in Bhutan, specifically the Tibetan (Vajrayāna) Buddhist Mahāyāna sutras and commentaries, which were subsequently analysed to trace gendered roles in Buddhist practice and explore the roots of women's subordination/ discrimination in the religious realm. 


\section{Concealing Objectivity or Confessing Subjectivity?}

Feminist researchers challenge claims to scientific objectivity and neutrality, which tend to obscure the lives and experiences of women (Benston 1982). Feminist writers such as Wallston $(1985,227)^{8}$ and Gross $(1996,13)$ reject claims of objectivity in women's studies, arguing, "The study of religion can never be value-free because the very existence of the discipline depends on this value". This argument is supported by Francine Blau (Blau and Jusenius 1976), ${ }^{9}$ who observed that three areas of research are inevitably influenced by values: the selection of the problems to be studied, the research methodology employed and the interpretation of the findings.

Gross (1996) explains how an individual's formative experiences help to shape the individual's theological outlook. Gross (2009) supports research on contemporary Buddhism that includes personal experiences of the Buddhist lifestyle, which she asserts should be included in the academic arena to provide a personal dimension in academic studies. This type of research enriches scholarship while at the same time acknowledging personal biases and tendencies.

The data collection methodologies employed in this research include elements of personal subjectivity (Lughod 1990; Klein 1995; Gross 1996), as the main researcher is a Buddhist nun who conducted participant observation among other Bhutanese Buddhist nuns. Far from being detached from the research subjects/ participants, she is of the same ethnic origin as most of the nuns, speaks the same language, is a citizen of the same country and understands the life of a nun and the difficulties faced by the research subjects as she underwent 13 years of monastic training in a nunnery.

In recognising the inevitable personal subjectivity in this research, we draw on Gross' (2009) assertion that rather than pretending to be objective, one should seek to minimise bias. Therefore, the main researcher acknowledged her personal subjectivity from the outset of the study so that the findings, debates and discussions may be understood in their proper context.

\section{The Research Process and Conclusions from the Ethnographic Study}

The main researcher participated fully in the daily activities of the nuns in the two nunneries studied. She gained entry to the nunneries through personal contacts with nuns at the nunneries and obtained a very deep understanding of the social 
dynamics of the community of nuns and their relationship with the local community and monks. This knowledge provided her with a basis for understanding gendered roles in Buddhist practice and limits to accessing monastic and secular education among nuns.

As a Buddhist nun herself, the main researcher participated in mundane activities such as daily work in the nunnery (chores such as cleaning and arranging the offerings) and spiritual activities such as performing daily prayers, meditation and prayers for the sick and deceased. This level of participation enabled her to gain the trust and respect of the nuns and the local community. Nonetheless, at one of the nunneries, two male laymen teachers accused her of conducting research for personal gain. Her attempts to explain the purpose of this research fell on deaf ears. The teachers' assertion had an enormous impact on the nuns and their relationship with the main researcher. She was unable to convince one-third of the nuns to talk to her, hindering the progress of the research. The teachers' interference in this research was monumental. This situation suggests that the male teachers did not take the researcher seriously, a fact that could be attributed to her being a nun challenging patriarchy in the monastic system.

The main advantage of ethnography is that research is conducted in a natural setting, providing the researcher with a clearer and less orchestrated account of what really goes on in the nunnery and the surrounding local community and the conditions influencing events. Being a full participant first and an observer second is a good way to blend in with the community so that the notion of "outsider" is eroded among the nuns and local community. One can observe while participating at the same time. Moreover, the main researcher had first-hand experience with participants and noticed things that ordinary observers failed to see. Therefore, she was able to confirm that a certain practice was conducted by the nuns/monks/ villagers. The level of experience and knowledge gained from full participation is difficult to obtain for an ordinary observer conducting only cross-sectional research.

The ethnographic study revealed that the roles of nuns in the two nunneries studied in Bhutan are largely gendered in a manner that denies nuns opportunities for personal development and empowerment, and consequently, opportunities to be fully socially engaged. It was found that the Bhutanese nuns play a minimal role in shaping the cultural and religious values of the communities with which they interact because they are confined to doing simple prayers and are not empowered to teach or to perform rites and rituals that may be of maximum benefit to laypeople. 
Nuns are still denied access to the systematic monastic education that is largely available to monks in Bhutan, and they face difficulties in meeting their basic needs, especially in the government-supported nunnery. Nuns also have low status in society, which is linked to the denial of monastic education and full ordination. Bhutanese nuns adhere to the Mūlasarvāstivāda ${ }^{10}$ Vinaya and are at best novice nuns $^{11}$ (Skt: śramanerikā; Tib: getsulma) who observe 36 monastic vows. ${ }^{12}$ Moreover, many are not ordained and are merely dressed in maroon robes. Nuns throughout the entire Tibetan cultural region lack access to full ordination (Skt: bhikșunī; Tib: gelongma) because the bhikșuṇi lineage purportedly never reached Tibet from India, and the male Buddhist clergy clings to this claim as an eternal truth. It is largely due to such obstacles and lack of opportunities that Bhutanese nuns are still not fully empowered to propagate Buddhism in their communities.

This study also uncovered various reasons for the subordination of nuns. However, the primary underlying factor is the patriarchal monastic body that has traditionally focused on developing men's spiritual potential to the highest level while neglecting female Buddhist practitioners, especially nuns whose lives are governed by policies dictated by these monastic bodies. In their own voices, the nuns declared that if they were empowered with the knowledge and skills monks possess in Bhutan, issues pertaining to finances and misogyny would eventually disappear. They are fully aware that gender barriers can be broken down only once they receive equal opportunities for spiritual development.

\section{A Glimpse of Narratives from the Ethnographic Study}

In the following sections, we provide excerpts from some of the insights gained from the ethnographic data with a specific focus on the grievances of nuns at both Jachung Karmo Nunnery in Western Bhutan and Jashar Goenpa in Eastern Bhutan. The narratives by the research respondents, Bhutanese nuns at both nunneries, provide deep and confidential insider perspectives on problems regarding basic needs and subsistence already identified through cross-sectional research, such as the study by Zangmo (2009). However, since the main researcher is herself a Bhutanese nun, she managed to access information that Zangmo (2009) could not as the latter is a laywoman and could not develop the level of intimacy required for this type of fieldwork. In the following accounts, pseudonyms are used to protect the identities of the nuns. The narratives begin with a descriptive analysis of the nunneries, their history and the founders and actors associated with the nunneries as retold by the nuns and members of the local communities as well as in supporting literature from Wangmo's (2013) publication, Nunneries of Bhutan (A Brief Guide). 


\section{In the Shadow of the White Eagle: Jachung Karmo Nunnery}

Jachung Karmo (White Mythical Eagle) was founded by a monk called Sewla Choje Lama Ngawang Pekar. The nunnery has been in existence for almost 300 years. Lama Ngawang Pekar appointed his sister, a nun named Rinchen Zangmo, as the first Lopenma or abbess of the nunnery. During her time, the nunnery flourished and is believed to have had more than a hundred nuns. Their main practice was the Nyungne fasting practice. Amazingly, these medieval nuns had the opportunity to engage in very advanced spiritual practices such as Mahammudrā, the Six Yogas of Naropa (Tib: Naro Choedrug), Choepa ro-nyom, and Drebu Tendrel Rabdun, which are not available to contemporary nuns. Nun Rinchen Zangmo was a highly advanced practitioner and is said to have achieved a special siddhi $i^{13}$ that enabled her to fly. With her last breath, she was believed to have used her spiritual powers to fly to Sha Phuntsho Pelri in Wangdi Phodrang district, never to be seen again, an indication of realisation of the spiritual path. Such was the spiritual ability of past women practitioners at Jachung Karmo.

In 1950, Jamyang Chöden, commonly known as Anim Lopenma Paldon, was appointed an abbess or Lopenma of Jachung Karmo at the age of 25 (Wangmo 2013). She received her practice training and guidance under several masters including Siddhi Metok Palzang, under whom she completed two 3-year retreats. She subsequently practised the Six Yogas of Naropa under the guidance of Dho Chorten Lopen Karma Tshering, Lama Sonam Zangpo and Lopen Namgyal, to name a few. The nunnery flourished under her leadership because she renovated the temple and consecrated many statues and other necessary ritual items for the nuns. She also introduced the practice of Nyungne,${ }^{14}$ the fasting retreat for which the nuns gained fame.

The nunnery was granted many acres of land from donors and sponsors hoping to secure prayers and merits for their ancestors and for their own good health and long and prosperous life. Donations of land have been extremely helpful for the long-term subsistence of the nuns and the nunnery. Anim Lopenma Paldon held the post of abbess for 25 years until 1975, when, at the age of 50, she passed on the responsibility to Lopenma Pekar Wangmo, sister of the Ex-Dorji Lopen of the Monastic Body, who is still alive in Talo Norbugang, Punakha. Not long after the second Lopenma Pekar Wangmo's tenure as abbess, the nunnery degenerated and all the nuns dispersed, leaving the nunnery empty and unattended to for approximately 16 years. 
The nunnery was revived by the fourth king of Bhutan, His Majesty King Jigme Singye Wangchuk. At the request of the Minister Japhag Dorji, the king reappointed Anim Lopenma Paldon as head of the nunnery in the summer of 1986, with 30 nuns living with her (Wangmo 2013). Lopenma administered the nuns and nunnery wisely and efficiently, advising the nuns to focus on their practice of Nyungne for their own benefit and that of the people. Furthermore, the nuns and nunnery grew stronger and gained respect and trust in society through the cultivation of the land donated by sponsors in the name of their deceased ancestors and support from the five Punakha villages (Pashikha, Kilikha, Talo, Nahay and Shegana) and Wangdi Phodrang. The nunnery land was given to farmers to cultivate for the nuns, and the harvest was shared equally between the nunnery and the farmers, with some labour input (collecting of harvest) by the nuns themselves. To help the nuns in collecting the harvest, the nunnery had a nyerpa ${ }^{15}$ from Talo for almost 15 years, until Guma gewog (sub-district) took over the responsibility. After three years, the nuns decided to collect the harvest on their own, and since then, this has been the nuns' responsibility. After Anim Lopenma's death, the nuns were left without a teacher or guidance for a long time. They struggled to run the nunnery but lacked knowledge of this type of management, as Zangmo (2009) suggests in her study.

A few years later, they found a teacher from Sha named Nyima who came to teach the rites and rituals, but not Buddhist philosophy and minor subjects pertaining to monastic studies. The teacher was appointed by the Je Khenpo ${ }^{16}$ and taught the nuns for seven years, after which he retired due to old age and poor health. After the teacher left, a few young nuns came to seek shelter at the nunnery, and the remaining senior nuns helped them with reading and chanting. In 1995, Her Majesty the Queen Mother Ashi Tshering Yangdon Wangchuk visited, and she has since taken care of the nunnery, providing drinking water and sanitation. In early 2012, Jachung Karmo merged with a larger privately run nunnery in Wolakha, and Punakha became their retreat wing. At the time of fieldwork, Jachung Karmo was home to 25 nuns ranging in age from 9 to 43 . Of these, 17 were nuns from the Wolakha Nunnery, whereas the remaining senior nuns had been with the nunnery between 2 and 26 years. Since the merger of the two nunneries, a new teacher, a 23-year old monk from one of the Phunaka monasteries, was appointed by the director of the Wolakha Nunnery.

\section{Jashar Goenpa: The Rising Rainbow}

Jashar Goenpa is a private nunnery in Eastern Bhutan run by a reincarnate (or Tib: trulku) male master, Gyaltshen Trulku Rinpoche. It is located in a village called Jashar Woong in Zobel gewog, Pema Gatshel district. This nunnery is associated with Anim Trulku, a female incarnate master who was a highly realised yogin $\bar{\imath}^{17}$ 
in her past life. It was founded by the previous incarnation of Anim Trulku and Anim Woesel Chöden, in the late 1950s but was taken over by Gyaltshen Trulku Rinpoche at the request of the local community and the students of the former due to its dilapidated state following the death of its female founder (Wangmo 2013).

The late Anim Woesel Chöden was from the village of Goenpa Singma, approximately three kilometres from the nunnery. She moved to a hilltop above Yongla Goenpa to live in solitary retreat away from people who might disturb her practice. However, at Yongla Goenpa, there were only monks and gomchen, ${ }^{18}$ and, as a nun, Vinaya ${ }^{19}$ rules prevented her from living with them. Hence, she lived alone in a small hut above the monastery. The protector deity of Yongla Goenpa, Tseringma, did not allow Anim Woesel Chöden to live peacefully and created many obstacles to her practice, disturbing her either in dreams or during meditation, so she decided to move. One morning, as she was looking out her window, she observed a rainbow in a particular place below. This occurred for a few consecutive days, with the rainbow appearing in the same place each time she looked down. She named the place Jashar Woong, meaning "the Ground of the Rising Rainbow", and in 1958 she built a temple there, which she named Jashar Goenpa, ${ }^{20}$ or "Temple of the Rising Rainbow" (Wangmo 2013). She lived in this temple with approximately 30 disciples comprising nuns, monks, laymen and laywomen. She later renamed the temple Jashar Lhundrub Choling. Anim Woesel Chöden was a student of the famous master Togden Shakya Shri I, an incarnation of Drubchen Saraha. ${ }^{21} \mathrm{He}$ had many disciples, nine of whom were considered very learned, and Anim Woesel Chöden, a woman, was at the top. She dedicated her life to meditation and remained in retreat until her death in 1982.

The nuns at Jashar Goenpa practice the Nyingma tradition of Vajrayāna Buddhism, although they have recently introduced the Drukpa Kagyu tradition, a blend of both in what is termed as Ka-Nying, a move to secure economic stability in the form of a monthly allowance from Dratshang Lhentshog. The nuns' practice here places greater emphasis on intensive retreats of three, six and nine years. The main deities of this nunnery are Guru Dewa, Tsendrali, Chenrezig and Amitabha, and their practices during retreats are based on the teachings and commentaries of Yogi Sakya Shri, an emanation of Maha Siddhi Saraha.

Jashar Goenpa is located in a scenic place above the main road from Samdrup Jongkhar to the town of Pema Gatshel, 11 kilometres before the town. A little further uphill from the conch-white chorten $^{22}$ are the nunnery entrance and a few small houses where old laymen and laywomen live in retreat. Jashar Goenpa is relatively well equipped compared to Jachung Karmo in Punakha. Jashar Goenpa has a large main temple, a common area for meditation, a guesthouse, toilet, 
kitchen and teacher's house. During fieldwork, there were 32 nuns present and 2 teachers, plus 9 more nuns in three-year retreats with 1 special attendant nun. The youngest nun was 14 and the oldest was 51 .

\section{Missed Opportunities and Exploitation: The Struggles of Bhutanese Nuns}

Nuns' struggle for subsistence is well known in Buddhist scholarship (Gutschow 2004, 111; Falk 2007). At Jachung Karmo, a government-supported nunnery, each of the 25 resident nuns receives a monthly stipend of 1,705 Bhutanese Ngultrum (Nu.) or USD28 from the central monastic body or Dratshang Lhentshog. ${ }^{23}$ Despite the stipend, the nuns still face financial constraints. After deducting Nu. 605 for food, they are left with only $\mathrm{Nu}$. 1,100 per month as pocket money or to buy necessities. As an added means of subsistence, some must perform labour at their natal homes in exchange for farm produce that they bring back to the nunnery, a phenomenon also observed among the Zangskari nuns in Gutschow's (2004, 155157) study. Yeshe Dolma explains, "When we go home, they only ask us to help to take care of the children, clean houses, wash dishes, and look after the animals".

In this case, the main challenge directly related to the nuns' subsistence is the remote location of the nunnery. The nearest village is a three-hour walk from Jachung Karmo, and thus it is difficult for people to reach the nunnery and make offerings. This is not a problem in Jashar Goenpa because the nunnery is easily accessible by motor vehicle. The remoteness of Jachung Karmo poses other problems as well. Karma Sonam summarises the general difficulties plaguing the nuns at Jachung Karmo:

The biggest challenge we face is the lack of road access to the nunnery. We have to carry all our groceries either by horse or by ourselves. Besides, there is no proper housing, kitchen and toilet. Water is a big problem, too, because in the summer, the rainwater washes away all the drainage and pipes, and in the winter, the water turns into ice and snow and does not flow through the pipes. At night, it is very dangerous without electricity for a woman to access the outdoor toilet.

Other minor constraints faced by nuns at Jachung Karmo include lack of medical care due to the remoteness of the nunnery. A 17-year-old named Ugyen Zangmo has some first aid training and is the only link the nuns have to any medical care. She states:

When the nuns are not well, I have to check their temperature and blood, etc., and when the need arises to give medicine, I don't have it. The reason is that the main nunnery in Wolakha is a long distance away and there is nobody to bring the medicines here. 
At Jashar Goenpa, the main challenge is the lack of retreat huts for the nuns due to space constraints. Therefore, Sonam Dechen and her cohort, who have already completed the six-year retreat, could not extend their retreat to nine years and had to give the new batch of retreaters a chance to do the six-year retreat. Instead, the nuns had to take over the official duties of the nunnery. Sonam Dechen shares her difficulties:

While in the nunnery, I am unable to practice what I have done in the retreat because we have no time. The five retreaters were all appointed as nunnery officials, and we have a lot of responsibilities to run the nunnery as well as to take care of the young nuns. Being a steward, I have to run to the market every two or three days to get the groceries, and I have to run errands in the nunnery as it is my department's responsibility to take care of the food for everyone, including the reception of guests in the nunnery.

Based on the researcher's observations, the problems the Jachung Karmo nuns face today are largely due to the absence of any exit strategy for the nuns after the death of their abbess, Anim Lopenma. Although Anim Woesel Chöden also failed to establish an exit strategy at Jashar, the disciples there managed to ask Trulku Gyeltshen Rinpoche to take over the nunnery's management, which turned out to be a blessing for the nuns. In the case of Jachung Karmo, the nunnery is remote and the nuns had no support structure. In contrast, Jashar had a community of monks, nuns, laymen and laywomen who could support each other. The Jachung Karmo nuns were left to fend for themselves, often with dire consequences, as Karma Sonam recalls:

After Lopenma's demise, we had a tough time because we were ignorant of how to handle and run the nunnery. We did not have a teacher for eight years, and the people who used to help collect our share cheated. Even the people ploughing our land refused to give the proper share to the nuns. Many nuns left the nunnery in search of studies and teachers.

At other times, nuns are exploited on the basis of their poor educational attainment. In one incident, a monk teacher at Jachung Karmo allegedly misused nunnery funds and blamed the nuns to cover up his misdeeds. Namgay Lhamo explains:

Whenever the nyerpa and I present our monthly accounts, it is very transparent and clear because we do not mix the nunnery money and our personal cash while buying things. Yet the moment we hand over the accounts to our teacher, he always finds a fault with our calculations. The teacher has been taking advantage of our poor mathematics by making us pay from our own pocket money to account for the so-called shortage. 
We did not argue much as it was always a minor sum of Nu. 300 to 500. However, whenever we hand over the cash to him to buy things for the nunnery, he does not give us an account of the money, not even a single receipt. When questioned, he becomes angry and defensive. The last straw was when he accused us of misappropriating Nu. 100,000 and demanded that we pay for it!

In addition, nuns face the threat of physical violence from their teachers. Tshering Yuden of Jachung Karmo shares her story of how she and Namgay Lhamo were nearly whipped after being wrongfully accused of breaking nunnery rules:

In mid-January 2013, the drunyig ${ }^{24}$ and I requested the three weeks' leave to go to an international conference on Buddhist women in India as our sponsor had invited us. The teachers refused to give us leave, but after explaining that it was an educational tour and the conference was within our capacity and that we need some exposure, they accepted our application. Once back in the nunnery, the teachers assembled all the nuns in the prayer hall and summoned both of us to the front just after the evening protector deity prayer. Standing in front of the entire assembly of nuns, the head teacher took out a leather whip and said we would be whipped for not abiding by the nunnery rules-leaving the nunnery without permission. We were shocked and explained that it was they who had given us permission to attend the conference and that it was for educational purposes, not to waste time. We were released because all the nuns pleaded on our behalf. It was a great humiliation for us because we are senior nuns, yet we were disgraced in front of all the junior nuns for no reason.

Not long after this incident, both Namgay Lhamo and Tshering Yuden left Jachung Karmo due to repeated disturbances from nunnery authorities and because the nuns were forced to work to rebuild the nunnery, depriving them of their practice time. The nuns were made to oversee food and drinks for the construction workers and take care of the nunnery. Moreover, despite their previous autonomy, the Jachung Karmo nuns were forced under the full control of the sister nunnery, Wolakha, which is run by monks. Monks in positions of authority took it upon themselves to censure and control the senior nuns into submission, which Gutschow (2004) confirms in her ethnographic study of nuns in Zangskar.

During fieldwork, the senior nuns reported that the annual rice harvest promised by the five villages that had been supporting Jachung Karmo for more than five decades was usurped by Wolakha. Immediately after the merger, Wolakha sent army personnel ${ }^{25}$ to collect the rice harvest, meaning that nothing from the harvest, 
which was meant exclusively for Jachung Karmo according to a traditional pact between the late Anim Lopenma and villagers, was taken from Jachung Karmo that year. By the time the senior nuns at Jachung Karmo determined that they had been cheated, the rice had been consumed by the nuns at Wolakha, and not a single grain was left. The nuns were indignant but kept quiet because they were controlled by Wolakha. If they complained, they would be scolded or punished. For years, the harvest had been used only for nunnery prayers, and the rest was sold to obtain the necessary cash to manage the nunnery. The senior nuns said that they never consumed a single grain of rice in all those years. Not only was the harvest taken, but the sister nunnery was also coveting Jachung Karmo's excellent quality musical instruments under the pretext of fine-tuning them, and the nuns tried several times to take these instruments to Wolakha. There were lingering suspicions amongst the senior nuns and even the local communities that the merger of the two nunneries was an economic strategy to usurp the resources of the oncewealthy Jachung Karmo. It became apparent that the sister nunnery sent the 18 nuns up to Jachung Karmo only to benefit from the monthly stipend. ${ }^{26}$ One senior nun explained:

Twenty-five nuns including the nun teacher used to receive the monthly stipend, but the nun teacher's share was later channelled to the monk teacher who never taught us even a single day. His stipend is the highest, Nu. 3,700 per month.

As indicated, it appears obvious that the nuns at Jachung Karmo were under total submission, and their lives were made difficult in an effort to drive them out of the nunnery. This is exactly what occurred less than a year after the conclusion of fieldwork. Namgay Lhamo shares the story of her life after leaving Jachung Karmo, which turned out to be equally difficult, if not worse:

We were tormented both physically and mentally in different ways, and eventually five ${ }^{27}$ of us left the nunnery. In our new place, a group of laypeople had pledged to build us seven retreat huts, as they already have the village temple not very far from Jachung Karmo, which was close to our teacher as well. While waiting for our retreat huts to be constructed, we lived in the temple building, sharing the rooms for seven months. When the retreat huts were not forthcoming, we inquired with our supporters, who told us that they were asked by Dratshang Lhentshog not to build retreat huts for the nuns and not to help us as well because nuns cannot stay and practice close to the monks' retreat place and the nuns cannot be at a higher spot from the village as it is a bad sign for the villagers. From every angle, we were the targets of either the laypeople or the monks. 
Whether it was an excuse by the villagers or an order from the monastic body, it is clear that nuns in Bhutan find it difficult to survive on their own outside their nunneries. Nuns still lack retreat facilities, a gap Dratshang Lhentshog has yet to address. It is not necessary for every nun to live in a nunnery; many wish to enter into retreat and need a decent place for that purpose. Although Jachung Karmo is ideal in terms of its location, the actual conditions at the nunnery are not conducive to spiritual practice because nuns have neither the time nor the peace of mind to practice. Namgay Lhamo continues:

All five of us had to disperse in different directions to find a suitable
place to practise. Two nuns went to Lungten Wangmo's hut between
Jachung Karmo and Punakha. Her hut could only accommodate one nun,
so the second nun could not go for retreat. The second one ended up
helping her host in the construction of her uncle's monastery. Another
was forced to return to her village and home to live with her parents
and siblings and to perform chores in return for shelter and food, with
no time for spiritual practice. Tshering Yuden and I were quite lucky
to have found two small huts for ourselves from an old friend in an old
nun's community, though we had quite a bit of renovation to do before
we could use them for our retreat. The roofs were leaking, the place was
drenched and moist, without a bathroom or toilet. We had to construct
one because while in retreat we cannot go out as we are not allowed to
meet people or talk to them. We had to repair the water source and pipes
to ensure adequate water supply for the entire duration of our retreat.

Since both Namgay Lhamo and Tshering Yuden lacked sufficient money ${ }^{28}$ to construct the toilet and bathroom and for their own daily use, they had to resort to shabten $^{29}$ for much-needed income. However, this drew the ire of their hosts, as Namgay Lhamo recalls:

The problem women face is never ending, as the owner of the retreat huts who let us stay there was not happy with us going for shabten since we were supposed to be in retreat. For that reason, they sold off the retreat huts to another person without our knowledge after we had almost completed the renovation works! People never understand our situation and difficulties, and think we can just sit and meditate without food and drink, but we are still human beings and we need basic requirements such as food and shelter to protect us from the harsh winter and wet summer. In the past, monastics could live under trees in the forest as they went for alms-round and there was no harm and danger from humans, which is not the case today. From all directions, we feel that we are experiencing suffering just because we are female practitioners. 
Regarding the issue of subsistence, the nuns at Jashar Goenpa had not received their monthly stipend from Dratshang Lhentshog for months. A monk entrusted with delivering the monthly stipend for the 30 nuns (out of 50) had not disbursed a total of one year's stipend to them. At the time of fieldwork, each nun's stipend was $\mathrm{Nu} .1,705$ per month, totalling Nu. 613,800 per year. Each time the nuns called him to enquire, he always made an excuse. The stipend is important to the nunnery because a portion of it is deducted for all the nuns and teachers' meals given that the income from the shabten is insufficient to cover the cost of food and management of the nunnery. The nuns appear to lack a channel for voicing their grievances to Dratshang Lhentshog, nor does the monastic body have a fool proof system for ensuring that the samgh $a^{30}$ receives their share. The nuns, not wanting to jeopardise their relationship with the monk, remain silent. Understandably (although ironically), this eerie silence perpetuates the vicious cycle of subordination and marginalisation of female Buddhist practitioners (Gutschow 2004; Schaeffer 2004; Falk 2007).

\section{Conclusion}

The omission of women from Buddhist literature has resulted in gaps in knowledge regarding women Buddhist practitioners, their achievements and their contribution to their respective communities. To bridge the gap in scholarship on Bhutanese nuns' religious lives, we employed an ethnographic study focusing on gendered roles in Buddhist practice in Bhutan to understand the current problems faced by ordained female Buddhist practitioners (i.e., nuns) in that country. The results of this ethnographic study have provided new knowledge regarding gender roles in institutional Buddhism in Bhutan and the role of contemporary female Buddhist practitioners in Bhutan.

We reiterate that no previous ethnographic studies have provided deep insights into the role of female practitioners, especially nuns in Bhutan. Hence, relevant literature on Bhutanese nuns could not be corroborated, with the exception of one cross-sectional study and another general publication on nunneries in Bhutan. The overall purpose of this ethnographic study on Bhutanese nuns was to give the nuns a platform to tell their stories and voice their grievances. Since they have been invisible since the advent of Buddhism in Bhutan, we believe that the time is right to correct the gender imbalance in Buddhist scholarship on Bhutan, which can only be possible through a credible and rich academic study of the nuns - in this case, by another Buddhist nun. This credibility is derived from ethnography. 
When nuns were given the opportunity to speak, they revealed layers of grievances and suppressed emotions that are ultimately tied to their female gender. The nuns at Jachung Karmo spoke about how they were deprived of teachers, basic means of subsistence, time to practice and even peace of mind. They lamented that they lacked support from the nunnery authorities run by monks, the monastic body and even local communities that exploit them. Nuns at Jachung Karmo are virtually cut off from the local communities because the nunnery is in the mountains with no road access. Hence, the nuns receive little sponsorship from local communities, except for the Nyungne practice conducted for deceased and sick relatives. Even male teachers refuse to travel to the nunnery to teach the nuns. The teacher (a monk) was not teaching anything to the nuns.

The nuns at Jashar Goenpa seized the opportunity to tell of their difficulties in terms of their exploitation by monks who refuse to hand over their monthly stipends from Dratshang Lhentshog, thereby forcing them to earn money for their nunnery through shabten. Echoing the grievances of their sisters at Jachung Karmo, the nuns at Jashar Goenpa also described having little time to practice. They also shared that the lack of a retreat facility forced the meditator nuns to take up nunnery management positions that disturb their practice.

These grievances and the situation of the nuns in general have never been described in any study. Thus, nuns remained invisible and their voices confined to the four walls of their nunneries. It is through this type of ethnographic research that they can gain a platform to share their concerns and difficulties as Bhutanese nuns in the hope that the results of this research will influence policymakers in Bhutan regarding women and religious practice as highlighted in the country's government and monastic institutions.

\section{Notes}

1. Samsāra is a Sanskrit word which means going or wandering through, undergoing transmigration; course, passage, passing through a succession of states, circuit of mundane existence, transmigration, metempsychosis, the world, secular life, worldly illusion.

2. White-robed ten-precept nuns in Thailand.

3. Religio-political is a term coined by the authors of this paper to showcase the inseparability of politics and religion in Bhutan.

4. Also known as Guru Rinpoche (Precious Master) or Lopen Pemajungney (Lotus Born Master).

5. Note that the abbreviation Tib. refers to Tibetan and Skt. refers to Sanskrit. Wherever terms are similar between Tibetan and Dzongkha, the abbreviation Tib. is used. Dzongkha is only mentioned when the term differs from the Tibetan language. 
6. The Nebraska Sociological Feminist Collective (1983) as mentioned in Ollenburger and Moore (1998).

7. According to Wangmo (2013), there are currently 21 nunneries in Bhutan, with an estimated population of slightly more than 1,000 nuns.

8. Cited in Ollenburger and Moore (1998).

9. Ibid.

10. The Vinaya texts extant today are from the schools of early Buddhism: Mahāvihāravāsin, Dharmaguptaka, Mahīśāsaka, Mahāsañghika, Lokuttaravāda, Mūlasarvāstivāda, Sarvāstivāda, of which only Mahāvihāravāsin, Dharmaguptaka and Mūlasarvāstivāda are a living tradition. Tibetan Buddhist monks and nuns follow the Mülasarvāstivāda.

11. There are five levels of monastic ordination in Buddhism: bhikșu and bhikșuñ (fully ordained monks and nuns respectively), śikșamānā (Tib: gelopma) (a 2-year probationary nun), śramanera (novice monk) and śramanerika (novice nun). The Vinaya are a derivate of the basic 10 precepts. Laymen are known as upāsaka (Tib: genyenpa) and laywomen are known as upāsika (Tib: genyenma); they observe the five lay precepts.

12. These 36 vows are based on the 10 precepts prohibiting the following: (1) intentional killing of a human being; (2) stealing; (3) sexual intercourse (both heterosexual and homosexual, involving penetration); (4) lying about one's spiritual attainment; (5) taking intoxicants; (6) singing, dancing, playing music; (7) wearing perfume, ornaments or cosmetics to beautify the body; (8) sitting on a high or expensive bed or throne; (9) eating after midday; and (10) touching gold, silver or precious objects (including money) (Chödron 2013).

13. Sanskrit (Skt): siddhi, refers to accomplishment, performance, fulfillment, complete attainment (of any object), success or attainment of supernormal powers.

14. Nyungne is a fasting practice focused on the 1000-Armed Avalokitéśvara (Tib: Chenrezig), the Bodhisattva of Compassion. The Nyungne practice originated from Bhikșuṇi Lakșmī (Tib: Gelongma Palmo), a princess from Uddiyana (in presentday Pakistan) who is believed to have lived during the 10 th or 11 th century $\mathrm{CE}$ (Common Era).

15. Steward of the nunnery.

16. Supreme Head of Religion in Bhutan.

17. Contemplative saint, devotee, ascetic (female) (Tib: naljorma).

18. Also known as Ngag-pa, a lay priest or a lay practitioner.

19. Sanskrit, for Monastic Code of Conduct (Tib: dulva). Since Anim Woesel Chöden was a śramanerika (Tib: getsulma), she is subject to the 36 śramanerika precepts, the fifth of which dictates the avoidance of sexual intercourse.

20. Also known as Jashar Woong Drubdey.

21. One of the Mahasiddhas considered one of the founders of Vajrayāna Buddhist and particularly of the Mahamudra tradition.

22. Meaning stupa in Tibetan.

23. Commission for Monastic Affairs.

24. Secretary of the nunnery.

25. Some royal armies linked to the nunnery. 
26. The total quota for Jachung Karmo's monthly stipend remains at 25 nuns. Because only three senior nuns are left at Jachung Karmo, the remaining stipend for 22 nuns is now channelled to the Wolakha nunnery.

27. Three from Jachung Karmo and two from its sister nunnery, Wolakha.

28. Now that they have left Jachung Karmo, they are no longer entitled to the monthly stipend from Dratshang Lhentshog.

29. Prayer services for the local communities.

30. Sanskrit for ordained Buddhist monastics (monks and nuns) (Tib: gedun).

\section{References}

Allione, T. 2000. Women of wisdom. n.p.: Snow Lion.

Aris, M. 1986. Sources for the history of Bhutan. Vienna: Arbeitskreis fur Tibetische und Buddhistische Studien.

Aziz, B.N. 1987. Moving towards a sociology of Tibet. In Feminine ground: Essays on women and Tibet, ed. J.D. Willis, 76-95. Ithaca: Snow Lion Publications.

Benston, M. 1982. Feminism and the critique of scientific method. In Feminism in Canada. Firm pressure to politics, eds. A. Miles and G. Finn, 47-66. Montreal: Black Rose Books.

Blau, F. and Jusenius, C.L. 1976. Economists' approaches to sex segregation in the labor market: An appraisal. Signs 1(3): 181-200. https://doi.org/10.1086/493286

Choden, K. 2005. The circle of karma. New Delhi: Penguin Books India in association with Zubaan Books.

Chödron, T. 2013. Ordination of Buddhist nuns. http://www.thubtenChödron.org/2013/05/ bhikșun̄ī-full-ordination/ (accessed 24 August 2015).

Crins, R. 2008. Meeting the "other" living in the present, gender and sustainability in Bhutan. n.p.: Uitgeverij Eburon.

Crossette, B. 1995. So close to heaven: The vanishing Buddhist kingdoms of the Himalayas. New York: Random House.

Denman, B.D. and Namgyel, S. 2008. Convergence of monastic and modern education in Bhutan? International Review of Education 54(3/4): 475-491. https://doi. org/10.1007/s11159-008-9085-0

Dowman, K. 2000. The divine madman: The sublime life and songs of Drukpa Kunley. Varanasi: Pilgrims Publishing.

Falk, M.L. 2007. Making fields of merit: Buddhist female ascetics and gendered orders in Thailand. n.p.: Nias Press.

Gross, R.M. 1993. Buddhism after patriarchy: A feminist history, analysis, and reconstruction of Buddhism. Albany: SUNY Press. 1996. Feminism and religion. Boston, MA: Beacon Press Books.

2009. A garland of feminist reflections: Forty years of religious exploration. Berkeley, CA: University of California Press. https://doi.org/10.1525/ california/9780520255852.001.0001

Gutschow, K. 2004. Being a Buddhist nun: The struggle for enlightenment in the Himalayas. London: Harvard University Press. 
Jacoby, S. 2014. Love and liberation: Autobiographical writings of the Tibetan Buddhist visionary Sera Khandro (1st ed.). Columbia: Columbia University Press. https://doi. org/10.7312/columbia/9780231147682.001.0001

Klein, A.C. 1995. Meeting the great bliss queen: Buddhist, feminist, and the art of the self. Delhi: Motilal Banarsidass Publishers Pte Ltd.

Lughod, L.A. 1990. Can there be a feminist ethnography? Women \& Performance: A Journal of Feminist Theory 5(1): 7-27. https://doi.org/10.1080/07407709008 571138

Mittra, S. and Kumar, B. 2004. Encyclopaedia of women in South Asia-Bhutan (vol. 7). New Delhi: Kalpaz Publication.

Ollenburger, J.C. and Moore, H.A. 1998. A sociology of women: The intersection of patriarchy, capitalism, and colonization. Upper Saddle River, NJ: Prentice Hall.

Penjore, D. 2005. Oral construction of exile life and times of Künkhyen Longchen Rabjam in Bumthang. Journal of Bhutan Studies 13(2): 60-73.

Phuntsho, K. 2005. On the two ways of learning in Bhutan. Journal of Bhutan Studies 2(2): 96-126. http://www.dspace.cam.ac.uk/handle/1810/227004

2013. The history of Bhutan. Uttar Pradesh: Random House India.

Schaeffer, K.R. 2004. Himalayan hermitess: The life of a Tibetan Buddhist nun. New York: Oxford University Press. https://doi.org/10.1093/ acprof:oso/9780195152999.001.0001

Simmer-Brown, J. 2002. Dakini's warm breath: The feminine principle in Tibetan Buddhism. Boston and London: Shambala.

Wallston, B. 1985. Feminist research methodology from a psychological perspective: Science is the marriage of agentic and communal. In Women's worlds: From the new scholarship, eds. M. Safir et al., 226-233. New York: Praeger.

Wangchuck, D.W. 2006. Treasures of the thunder dragon: A portrait of Bhutan. New Delhi: Penguin Global.

Wangmo, T. 2013. Nunneries of Bhutan (a brief guide). Phuentsholing: Kuensel Corp. Ltd. Wikan, U. 1996. The nun's story: Reflections on an age-old, postmodern dilemma. American Anthropologist (New Series) 98(2): 279-289. https://doi.org/10.1525/ aa.1996.98.2.02a00050

Zangmo, T. 2009. Women's contribution to gross national happiness: A critical analysis of the role of nuns and nunneries in education and sustainable development in Bhutan. $\mathrm{PhD}$ dissertation, University of Massachusetts Amherst, Amherst, MA. 